\title{
The globalized gene
}

\author{
The global genome: biotechnology, \\ politics, and culture \\ Eugene Thacker \\ Cambridge, Mass.: MIT Press; 2005 \\ 434 pp US\$39.95 (cloth) ISBN 0-262-20155-0
}

I t was with some trepidation that I ventured into the world of The Global Genome: Biotechnology, Politics, and Culture, not so much because of the subject matter as the fact that the author, Eugene Thacker, is a professor of literature, communication and culture. Indeed, this book is part of a series from MIT Press that is "envisioned as a catalyst ... for diverse intellectual communities to explore common grounds of expertise ... in the evolving arena where art and science connect." Here, however, the intersection is that of biology with informatics.

Navigating as it does between the encoding and production of genomic information, its distribution in the form of international biocolonialism and biowarfare and the possibility of personally decoding and consuming through regenerative medicine, The Global Genome artfully achieves its ambitious aims.

This is not to say, however, that it does not wax rhetorical at times. In fact, resembling a cross between Alvin Toffler's Future Shock (1970) and Juan - Enriquez's As the Future Catches You (2000), the book is at times arduous reading. We plough through Foucault's biopolitics, as well as Karl Marx and Georges Canguilhem, to name but a few philosophers summoned in Thacker's critical analysis of the triangulated relationship between DNA, databases and tissues in the redefinition of "life itself." Biology is seen as information - both material and immaterial, transformed into a technology itself: "In biopolitics, the body is a database, and informatics is the search engine." In particular, the Human Genome Project and population genomics come under heavy criticism as concerns the great patent debate and the medicalization of the notion of populations themselves the population as the new territory of biocolonialism.

In spite of the overall richness of this book, the chapters on "Genomics and Databasing" and on "The Incorporate Bodies of Recombinant Capital" (that is to say, the correlations between medical and economic value systems) are particularly weak, and this for several reasons. search tools and not a population database.

Second, these chapters are not wholly accurate in their understanding of population genomics and human diversity. Indeed, the author (like many others before him) demonizes Luca Cavalli-Sforza and the Human Genome Diversity Project (again, a project that never began). In fact, the recent results of the HapMap have served to validate Sforza's ideal of dissociating race from biology. Polymorphic differences reorganized in ancestral genomic blocks (haplotypes) show few "racial" differences. Race, however, cannot be discounted as a sociopolitical and cultural phenomenon with visible economic and health consequences.

Finally, bioinformatics and the biotech industry are reduced to "the continual transformation of biological

\section{Ten years ago, the fear was of the genetization of society; now it is the realization of the fictional X-Men.}

First, they are not contemporary, presuming as they do that DNA Sciences (a large-scale organized DNA sample bank) and its Gene Trust still exist, whereas they were abandoned in 2003. Likewise for the Tonga Gene Bank (Autogen), which in fact never began. Furthermore, the $\mathrm{P}_{3} \mathrm{G}$ (Public Population Project in Genomics) is actually an open-access resource for re- value and medical value into economic value, a continual refashioning of the species being as at once biological and economic, as a form of 'biomaterial' labor." Likewise, biowarfare and biological security are depicted as political pretexts for power-grabbing through the normalization of states of emergency.

In contrast, the chapter on tissue 
engineering and regenerative medicine, while remaining critical, is more tempered and realistic. " $[R]$ egenerative medicine is largely concerned with ensuring the body's protection from the dangers of certain contingencies that threaten its well-being." Thacker's critique is that, like the genecentric, reductionist approaches found in biotechnology, the concentration on the capacity of the body to "regrow" itself de-emphasizes environment and context such that the body is viewed in a cellular vacuum. According to the author, the concept of human labour the real-time labour of the physical body - is replaced by the archival "labour" of cell cultures, databases and plasmid libraries. Ten years ago, the fear was of the genetization of society, while now it is of the technical redesign of life, the realization of the fictional X-Men.

This book constitutes a critical analysis of the integration of information and biotechnology. The challenge is to rethink the vitalist ideology of the life sciences. It offers a framework for a futuristic examination of current "advances," whether one agrees with the author's conclusions or not. The challenge offered by Thacker is to question whether the "complex" properties of "biological life itself" will lead us to innovation in both our thinking on the relation between the human and the nonhuman and in the fashioning of prospective policies.

\section{Bartha Maria Knoppers}

Canada Research Chair in Law and Medicine

Centre de recherche en droit public Université de Montréal

Montréal, Que.

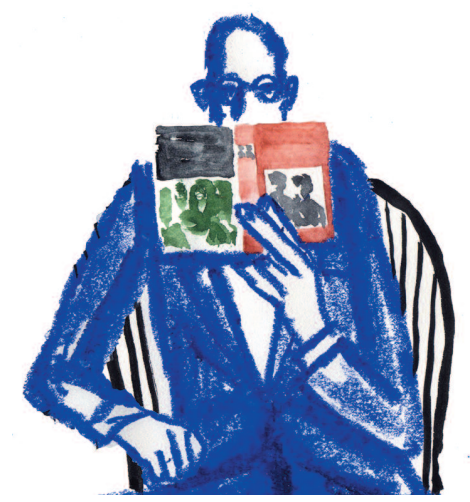

\section{Notes}

\section{Any resident's story}

11:14 I can't wait until l'm on staff. I'm gonna leave my watch at home every day. Maybe l'll just forget how to tell time altogether.

11:20 Okay, he should be here any minute now. No apology, of course. Not even an explanation. Is there an explanation? Stuck in traffic? Attacked by badgers? Trapped under something heavy, like his ego? Maybe he's looking after some really sick patient somewhere. Really sick, unlike his patients here, who are apparently only sorta sick and not really worth his time. Maybe someone's dying somewhere.

11:27 There'd better be somebody dying. Only excuse I can think of for being 27 minutes late.

11:31 There's nobody dying anywhere. Well, dying of iatrogenic boredom, maybe. I wonder who the victim is. Some poor patient? Another resident? Maybe it's some other staff jerk, who's seriously reconsidering ever asking for a curbside consult again.

11:36 I'd leave and try to get something useful done, but the second I do he'll turn up and blow a gasket because I'm not here waiting for him with his slippers in my mouth. Should I page him? No, he hates being paged. Whenever I page him he's in the middle of something important, like curing cancer or inventing oxygen or defribrillating the Pope.

11:41 Why am I even here? I've forgotten everything I was going to talk to him about. Dammit! Aww, it doesn't matter, anyway. He never wants to hear anything I have to say. Vitals? Bah! Meds? Phooey! Has the patient recently eaten nectarines? That's what he'll want to know. Has the patient ever been in a marching band? Has the patient now, or has the patient ever been, in possession of a humidor?

11:43 Oh, here he comes now. You'd think he was on vacation, the way he's meandering down the hall. Hey, wait a second ... he's got a coffee! He's been at Tim's for God's sake! That's it. He's really gonna get it now. I'm gonna take a piece outta him. Here I am waiting to talk to him about his patients, and he's getting a double-double and a muffin! I'm gonna ...

11:46 I really shoulda let him have it.

12:02 Well, I guess I won't be getting to that lunchtime teaching session. This is plenty educational, though. Listening to him go on about how residents today don't know how to do a physical exam is certainly going to make me a better doctor. I bet he knows of a study that says so.

12:08 Shut up. Please shut up. l'll pay you one hundred dollars to shut up. Seriously. Stop talking now.

12:14 Randomize this, you \$\%\&@!

Paul Moorehead

Pediatrics Resident

Memorial University of Newfoundland

St. John's, Nfld. 